\title{
SISTEM INFORMASI PENJUALAN MAKANAN KHAS KOTA PALU BERBASIS WEB
}

\author{
Deny Wiria Nugraha \\ Program Studi Teknik Informatika, Jurusan Teknik Elektro \\ Fakultas Teknik Universitas Tadulako Palu, Sulawesi Tengah \\ deny_wiria_nugraha@yahoo.co.id
}

\begin{abstract}
ABSTRAK
Penelitian ini bertujuan untuk merancang dan membangun sistem informasi penjualan makanan khas Kota Palu berbasis web untuk mendukung dan memfasilitasi proses penjualan dan pemasaran makanan dan menyajikan informasi yang lebih akurat, relevan, dan tepat waktu. Penelitian ini dilakukan melalui tahapan, yaitu observasi, perumusan dan identifikasi masalah, pengumpulan data, analisis sistem, desain sistem dan implementasi, dan pengujian sistem. sistem informasi penjualan makanan khas Kota Palu berbasis web yang dirancang dan dibangun dalam penelitian ini memiliki konsep e-commerce yang mampu melakukan perdagangan elektronik distribusi, penjualan, pembelian, pemasaran barang / produk, dan proses transaksi online. Sistem informasi ini dapat meningkatkan keunggulan kompetitif, antara lain, untuk memenuhi kebutuhan konsumen dengan cepat karena pembeli berhubungan langsung dengan penjual tanpa perantara, ketersediaan informasi produk yang akurat, memperluas jangkauan geografis, meningkatkan penjualan barang / produk, dan kenyamanan dalam bertransaksi tanpa perlu datang ke tempat penjualan sebagai cukup untuk melihat informasi pada website dan mengklik barang / produk yang diinginkan.
\end{abstract}

\section{Kata Kunci : information system, electronic commerce, competitive advantage}

\section{PENDAHULUAN}

Teknologi internet mempunyai pengaruh yang cukup besar dalam segala bidang. Penggunaan metode transaksi secara online sangat berkembang pesat, bahkan sampai pada beberapa aspek, dan kegiatan yang biasa dilakukan secara manual, sekarang dilakukan dengan menggunakan sistem online. Beberapa sistem yang implementasinya telah berkembang dengan menggunakan media internet adalah e-government (pelayanan pemerintah melalui internet), e-leaming (pembelajaran melalui internet), dan e-banking (transaksi perbankan secara online). Dalam dunia ekonomi, khususnya dalam hal penjualan, yang dilakukan melalui internet ini sering disebut dengan e-commerce (electronic commerce).

E-commerce semakin diminati karena beberapa keunggulan, seperti biaya operasional yang relatif murah dan kemudahan untuk melakukan manajemen barang yang diperdagangkan serta kemudahan dalam penyusunan laporan yang diperlukan, karena data yang ada adalah data pasti dengan perhitungan yang akurat. Selain itu terdapat pula kemudahan dari sisi konsumen, misalnya pembeli hanya dengan dari rumah atau dimana pun berada, dapat melihat produk-produk pada layar komputer, mengakses informasinya, memesan, dan membayar dengan pilihan yang tersedia. $E$ commerce perannya sangat vital dikalangan dunia bisnis berbasis komputer dan website, karena $e$ commerce dapat membantu dalam memecahkan masalah pada proses kerja, proses transaksi antara penjual dan pembeli yang menjadi lebih efisien, dan dengan kecepatan jangkauan. Kemudahan yang diberikan melalui layanan e-commerce tentunya dapat memberikan keuntungan pada semua pihak.

Mekanisme promosi dan penjualan makanan khas Kota Palu saat ini masih banyak dengan cara konvensional yaitu pembeli langsung datang ke toko yang menjual makanan tersebut. Strategi penjualan seperti ini sangat memungkinkan akan timbulnya masalah dikemudian hari, diantaranya pelanggan/pembeli yang lokasinya berjauhan atau berada di luar kota akan merasa keberatan untuk berbelanja di toko. Pengelolaan manajemen yang masih dilakukan secara manual dirasa cukup membebani manajemen karena untuk melakukan promosi dan penjualan membutuhkan biaya cukup besar untuk sarana media informasi dan bertransaksi dengan konsumen. 
Berdasarkan pada latar belakang di atas maka peneliti mengusulkan suatu sistem penjualan makanan khas Kota Palu berbasis web yang memiliki fungsi-fungsi pendukung penjualan dan diharapkan dapat membantu dalam meningkatkan hasil penjualan barang/produk.

Rumusan masalah dalam penelitian ini adalah bagaimana cara merancang dan membangun sebuah sistem informasi penjualan makanan khas Kota Palu berbasis web. Tujuan dari penelitian ini adalah merancang dan membangun sistem informasi penjualan makanan khas Kota Palu berbasis web untuk mendukung dan memudahkan proses penjualan dan pemasaran makanan tersebut serta menyajikan informasi yang lebih akurat, relevan, dan tepat waktu.

\section{TINJAUAN PUSTAKA}

\section{Sistem Informasi (Information System)}

Sumber dari informasi adalah data. Data adalah fakta atau kenyataan yang menggambarkan suatu kejadian-kejadian yang mempunyai arti tersendiri. Informasi adalah data yang telah diproses sedemikian rupa, sehingga memiliki arti yang lebih bermanfaat bagi penggunanya. Informasi merupakan aset penting bagi suatu institusi atau organisasi. Oleh karena itu, informasi harus berkualitas, dijaga, dan dipelihara dengan baik [1].

Sistem informasi merupakan gabungan dari empat bagian utama. Keempat bagian utama tersebut mencakup perangkat lunak (software), perangkat keras (hardware), infrastruktur, dan Sumber Daya Manusia (SDM) yang terlatih. Keempat bagian utama ini saling berkaitan untuk menciptakan sebuah sistem yang dapat mengolah data menjadi informasi yang bermanfaat. Didalamnya juga termasuk proses perencanaan, kontrol, koordinasi, dan pengambilan keputusan. Sehingga, sebagai sebuah sistem yang mengolah data menjadi informasi yang akan disajikan dan digunakan oleh pengguna, maka sistem informasi merupakan sebuah sistem yang kompleks [2].

Komponen-komponen yang terdapat di dalam semua jenis sistem informasi mencakup tujuh poin, yaitu input (masukan), output (keluaran), software (perangkat lunak), hardware (perangkat keras), database (basis data), kontrol dan prosedur, dan teknologi dan jaringan komputer. Komponenkomponen di dalam sistem informasi tersebut dapat dilihat pada gambar 1 .

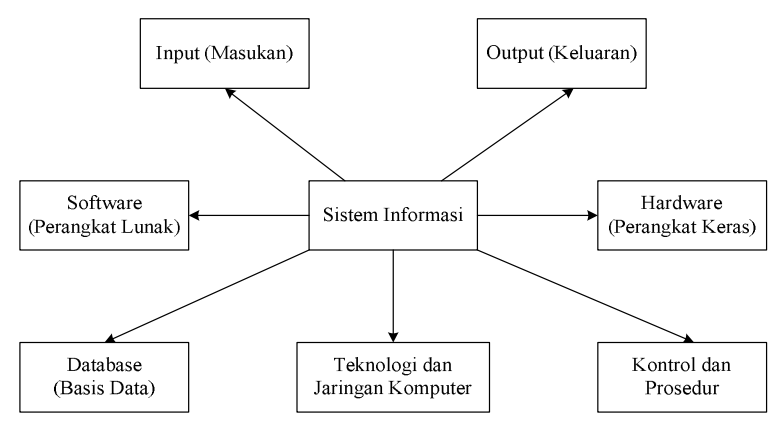

Gambar 1. Komponen-komponen di dalam sistem informasi [2]

\section{Aplikasi Sistem Informasi dan Keunggulan Kompetitif}

Aplikasi sistem informasi bisa dijumpai pada berbagai bidang dan digunakan untuk menangani berbagai aktivitas. Aplikasi dapat berbentuk desktop ataupun web. Aplikasi desktop dibuat dengan menggunakan berbagai perkakas pengembangan dan umumnya bergantung secara spesifik terhadap platform yang digunakan. Adanya kemudahan akses internet, aplikasi web menjadi pilihan banyak perusahaan. Selain kemudahan dalam meluncurkan rilis aplikasi yang baru (karena aplikasi cukup ditaruh di server dan tidak perlu diinstal pada setiap klien), aplikasi sangat mudah dijangkau oleh pengguna yang berada di mana saja. Sebagai implikasinya, aplikasi web dapat digunakan untuk memberikan layanan informasi atau bahkan sebagai media untuk melakukan transaksi jual beli [3].

Internet membuat persaingan menjadi semakin ketat. Bagi pendatang baru, memasuki pasar adalah hal yang mudah dan bahkan dapat memberikan harga yang lebih bersaing. Dari sisi pembeli, hal ini juga menguntungkan. Pembeli bisa melakukan pembandingan harga dengan mudah apalagi ditunjang keberadaan situs web yang berfungsi sebagai agen pembanding, sehingga pembandingan harga cukup dilakukan dengan melihat satu halaman web.

Internet bisa membantu perusahaan untuk menciptakan dan menangkap keuntungan dalam cara-cara baru dengan menambahkan nilai ekstra bagi produk-produk yang sudah ada atau dengan memberi fondasi untuk produk-produk dan layanan baru [4].

Dampak internet pada keunggulan kompetitif (competitive advantage) yaitu:

1. Ancaman pengganti produk/jasa: memungkinkan barang-barang pengganti muncul dengan pendekatan-pendekatan baru untuk memenuhi kebutuhan dan melaksanakan fungsinya. 
2. Daya tawar pembeli: ketersediaan informasi produk dan harga secara global menggeser daya tawar kepada pembeli.

3. Daya tawar pemasok: pengadaan barang/jasa melalui internet cenderung menaikkan daya tawar terhadap pemasok. Sebaliknya, pemasok juga mendapat keuntungan dari penurunan hambatan masuk dalam persaingan dan penghilangan distributor dan perantara lain yang berada di antara pemasok dan pembeli.

4. Ancaman pendatang baru: internet mengurangi hambatan untuk masuk dalam persaingan, misalnya tenaga penjualan, akses ke saluran penjualan, dan aset fisik.

5. Persaingan sesama: internet memperluas jangkauan geografis, meningkatkan jumlah pesaing, dan mengurangi perbedaan di antara para pesaing.

\section{Konsep E-Commerce}

Perdagangan elektronik atau e-dagang (electronic commerce atau e-commerce) adalah penyebaran, pembelian, penjualan, pemasaran barang dan jasa melalui sistem elektronik seperti internet atau televisi, www, atau jaringan komputer lainnya [5]. E-commerce dapat melibatkan transfer dana elektronik, pertukaran data elektronik, sistem manajemen inventori otomatis, dan sistem pengumpulan data otomatis.

Industri teknologi informasi melihat kegiatan $e$ commerce ini sebagai aplikasi dan penerapan dari $e$ business yang berkaitan dengan transaksi komersial, seperti: transfer dana secara elektronik, SCM (supply chain management), e-marketing atau pemasaran online, pemrosesan transaksi online (online transaction precessing), pertukaran data elektronik (electronic data interchange/EDI), dan lain-lain.

E-commerce merupakan bagian dari e-business, di mana cakupan e-business lebih luas, tidak hanya sekedar perniagaan tetapi mencakup juga pengkolaborasian mitra bisnis, pelayanan nasabah, lowongan pekerjaan dan lain-lain. Selain teknologi jaringan www, e-commerce juga memerlukan teknologi basis data atau pangkalan data (database), e-mail atau surat elektronik, dan bentuk teknologi non komputer yang lain seperti halnya sistem pengiriman barang, dan alat pembayaran untuk e-commerce ini.

Bahkan saat ini dengan adanya e-commerce, teknologi informasi memiliki peran yang sangat penting bagi perusahaan untuk melakukan promosi produk, sosialisasi berbagai jasa pelayanan, memberikan discount khusus, termasuk kerjasama antar mitra kerja dan pelaku bisnis, serta membuka bisnis baru di wilayah yang berpotensi. Kegiatan tersebut dapat dilakukan offline maupun secara online melalui situs website resmi.

\section{III. METODE PENELITIAN}

\section{A. Jenis Penelitian}

Penelitian yang dilakukan dalam hal ini adalah penelitian deskriptif kualitatif yang melakukan survei terhadap objek penelitian dengan mengumpulkan data dari toko yang menjual makanan khas Kota Palu. Tipe penelitian yang digunakan berdasarkan sifatnya merupakan penelitian Rekayasa Perangkat Lunak, yaitu dengan merancang dan membangun sistem informasi penjualan makanan khas Kota Palu berbasis web.

\section{B. Objek dan Waktu Penelitian}

Objek pada penelitian ini merupakan salah satu toko yang menjual makanan khas Kota Palu yaitu Toko MJ yang bertempat di jalan Beo nomor 4 Palu, Sulawesi Tengah. Penelitian ini dilakukan mulai dari bulan Agustus sampai dengan bulan Oktober tahun 2014.

\section{Jenis dan Sumber Data}

Berdasarkan sumbernya ada dua jenis sumber data yaitu data primer dan data sekunder. Data Primer merupakan data yang diperoleh secara langsung dari objek penelitian dan dari para responden melalui wawancara mengenai hal-hal yang berkaitan dengan objek penelitian. Data primer meliputi data jenis-jenis makanan khas Kota Palu yang dijual pada objek penelitian. Data makanan khas Kota Palu yang dikumpulkan merupakan jenis makanan yang bersifat kering dan dapat bertahan cukup lama. Sumber data sekunder diperoleh dari literatur-literatur seperti buku dan artikel yang berhubungan dengan masalah penelitian.

\section{Tahapan Penelitian}

Penelitian ini dilakukan melalui tahapan-tahapan sebagai berikut:

1. Melakukan observasi atau pengamatan langsung

Observasi dilaksanakan untuk melakukan pengamatan kondisi yang ada pada objek penelitian.

2. Perumusan dan pengidentifikasian masalah

Pada tahap awal ini yang dilakukan adalah merumuskan dan mengidentifikasi permasalahan yang ditemukan dari hasil observasi.

3. Pengumpulan data

Pada tahapan pengumpulan data ini, ada dua jenis data yang dibutuhkan, yaitu data primer dan data sekunder. 


\section{Analisa sistem}

Data primer yang dikumpulkan dari hasil wawancara langsung merupakan data mentah. Agar data tersebut dapat berguna bagi penelitian ini dibutuhkan suatu penyajian dan analisa data.

5. Perancangan dan implementasi sistem

Melakukan perancangan dan implementasi fisik seperti perancangan dan implementasi interface, database, dan pengkodean (coding). Tahapan perancangan dan implementasi sistem secara umum dilakukan setelah tahapan analisa sistem selesai dilakukan. Pada tahap perancangan dan implementasi, komponen-komponen sistem informasi yang akan didesain dikomunikasikan kepada user/pengguna.

6. Pengujian sistem

Pada tahap ini dilakukan ujicoba dan pengamatan pada sistem informasi yang telah dirancang dan dibangun, apakah sistem sudah berjalan sesuai yang diharapkan atau belum, dan apakah sistem sudah sesuai dengan kondisi yang ada pada objek penelitian.

\section{E. Analisa Sistem}

Analisa ini bertujuan untuk mengetahui sistem yang berjalan pada objek penelitian. Analisa sistem yang ada diperlukan untuk memecahkan permasalahan, mengetahui kelemahan-kelemahan sistem, serta kebutuhan sistem.

Adapun sistem yang berjalan pada objek penelitian dapat dijelaskan sebagai berikut:

1). Pelaksanaan penjualan masih dilakukan secara konvensional, di mana pembeli harus datang langsung ke toko untuk melakukan transaksi pembelian.

2). Penyebaran informasi untuk promosi produk dan keberadaan toko dirasakan belum efektif, masih diperlukan media lain dalam mengembangkan usaha.

3). Media yang digunakan selama ini yaitu informasi oleh pelanggan yang pernah membeli ke toko dan hanya terbatas pada daerah Kota Palu dan sekitarnya, sehingga belum mempunyai manfaat yang signifikan untuk perkembangan dalam dunia usaha.

4). Waktu proses penyebaran informasi kepada pelanggan tetap dan masyarakat lainnya sangat lambat.

Berdasarkan hasil analisa sistem yang ada tersebut, maka peneliti merancang dan membangun sebuah sistem informasi makanan khas Kota Palu berbasis web seperti digambarkan dalam blok diagram pada gambar 2 .

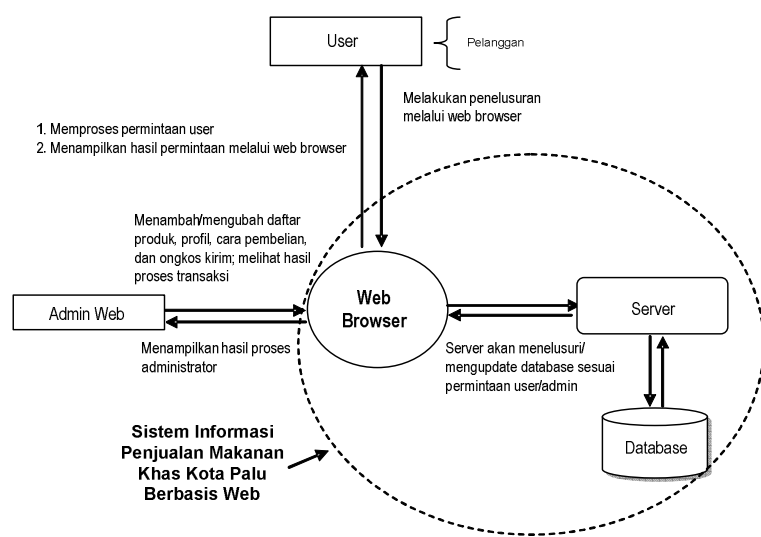

Gambar 2. Blok Diagram

\section{Data Flow Diagram/DFD (Diagram Arus Data)}

Diagram Arus Data/Data Flow Diagram (DFD) menggambarkan aliran data dan dokumen pada sistem informasi yang dirancang dan dibangun ini. Adapun DFD level 0 (Diagram Konteks) dan DFD level 1 pada penelitian ini dapat dilihat pada gambar 3 dan gambar 4.

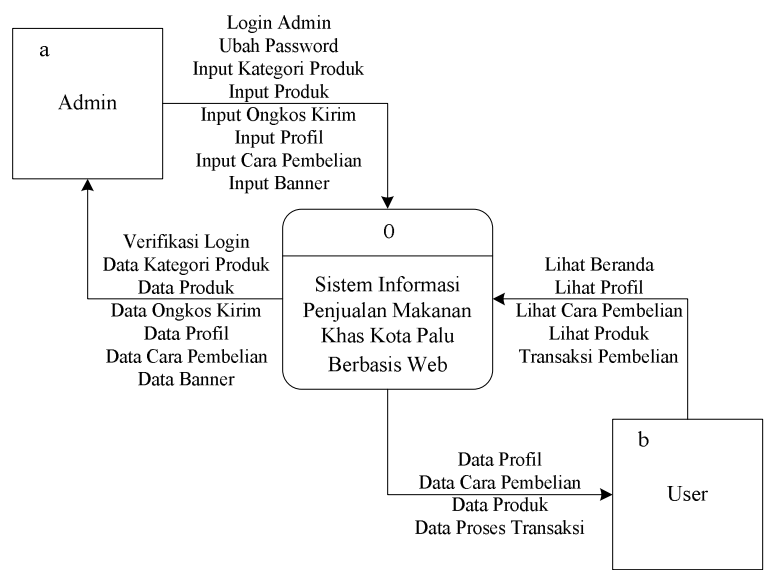

Gambar 3. Diagram Konteks (DFD level 0)

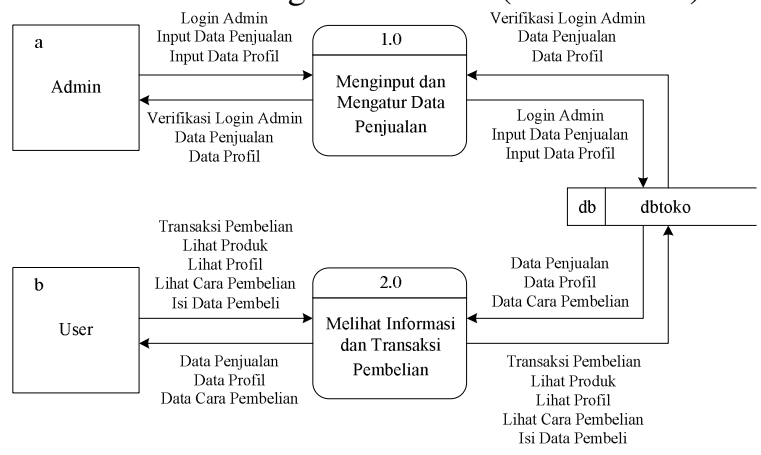

Gambar 4. DFD level 1

\section{Desain Database}

Sistem informasi yang dirancang dan dibangun pada penelitian ini menggunakan sepuluh tabel dalam databasenya. Adapun tabel-tabel tersebut 
dapat dilihat dalam bentuk ER-Schema (Entity Relationship-Schema) pada gambar 5.

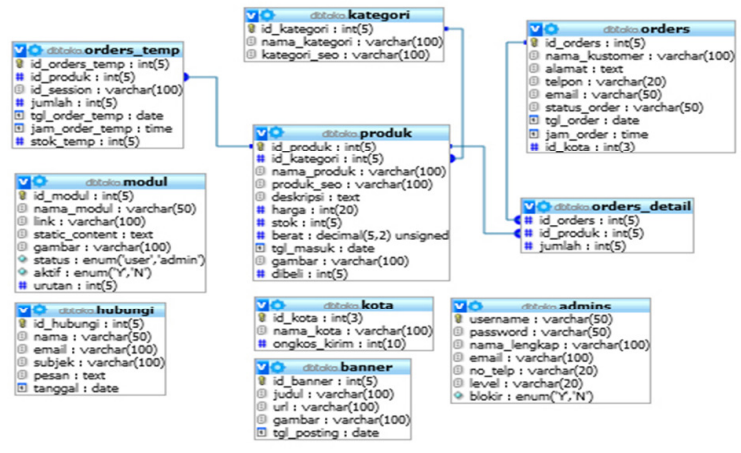

Gambar 5. Tabel-tabel dalam database

IV.

\section{IV. HASIL DAN PEMBAHASAN}

A. Spesifikasi Perangkat Keras dan Perangkat Lunak yang Digunakan

Dalam implementasinya, sistem informasi yang dirancang dan dibangun dalam penelitian ini menggunakan perangkat pendukung berupa perangkat keras (hardware) dan perangkat lunak (software). Adapun perangkat-perangkat tersebut dapat dijelaskan sebagai berikut:

1. Personal Computer (PC)/Laptop dengan Processor Intel(R) Atom(TM) CPU N550 @ $1.50 \mathrm{GHz}$.

2. Random Access Memory (RAM) 1 GB.

3. Hardisk kapasitas 160 GB.

4. Sistem Operasi Microsoft Windows 7 Ultimate.

5. Web Server: XAMPP for Windows versi 1.7.7.

6. Web Browser: Internet Explorer atau Mozilla Firefox.

\section{Database MySQL.}

\section{B. Hasil Tampilan Antarmuka (Interface)}

Sistem informasi penjualan makanan khas Kota Palu berbasis web yang telah dirancang dan dibangun dalam penelitian ini memiliki beberapa form yang mempunyai fungsinya masing-masing. Form-form tersebut akan tampil sesuai menu yang dipilih. Secara garis besar form-form tersebut terdiri dari dua, yaitu form masukan (input) yang merupakan awal dimulainya proses informasi dan form keluaran (output) yang merupakan produk sistem informasi yang dapat dilihat. Adapun tampilan antarmuka (interface) sistem informasi ini dapat dilihat pada gambar 6, 7, 8, 9, 10, 11, 12, dan 13 .

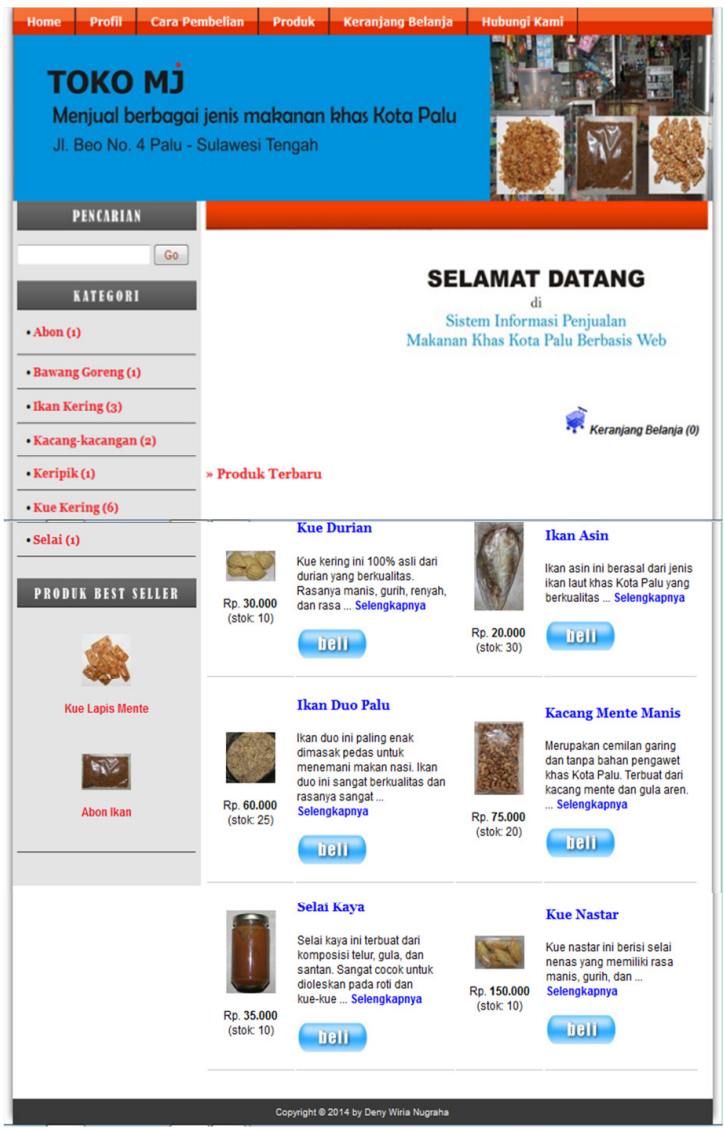

Gambar 6. Tampilan menu utama/beranda

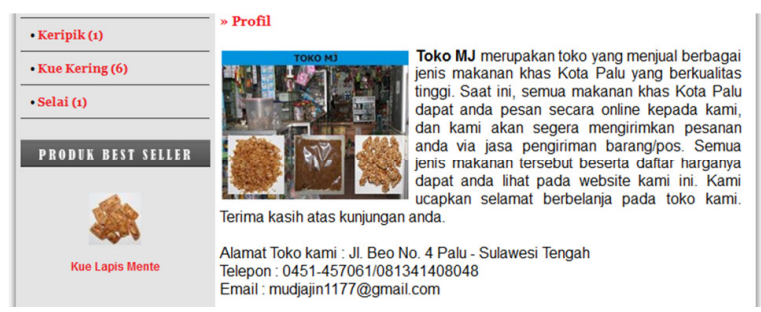

Gambar 7. Tampilan menu profil

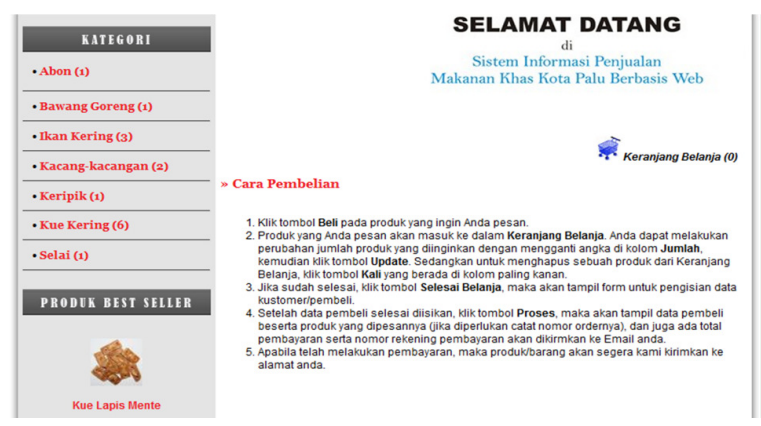

Gambar 8. Tampilan menu cara pembelian 


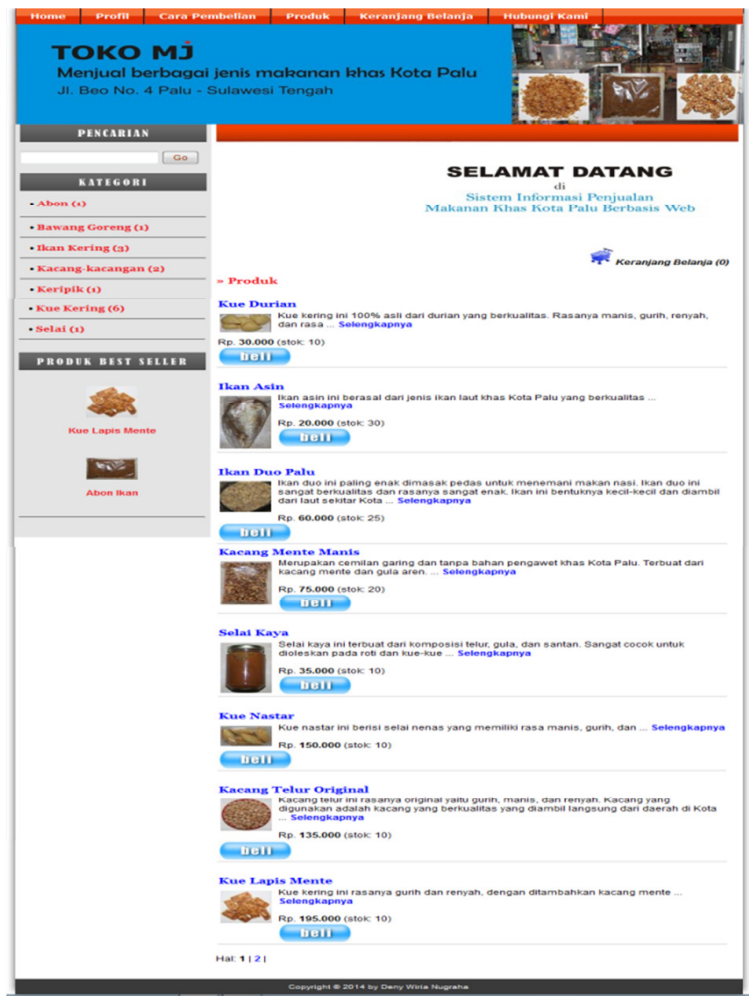

Gambar 9. Tampilan menu produk

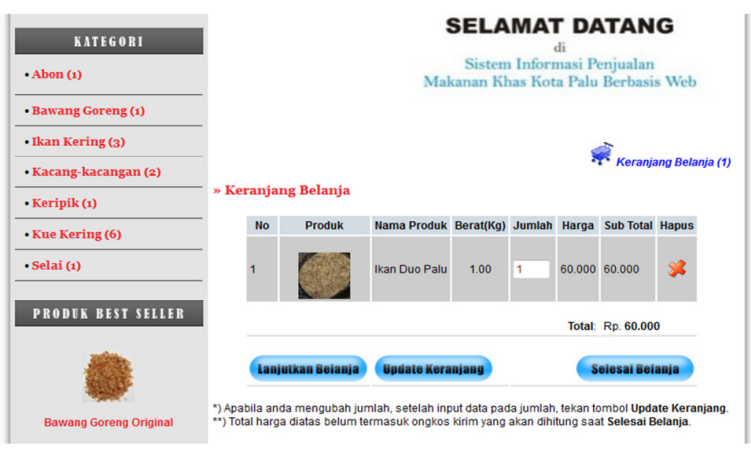

Gambar 10. Tampilan menu keranjang belanja

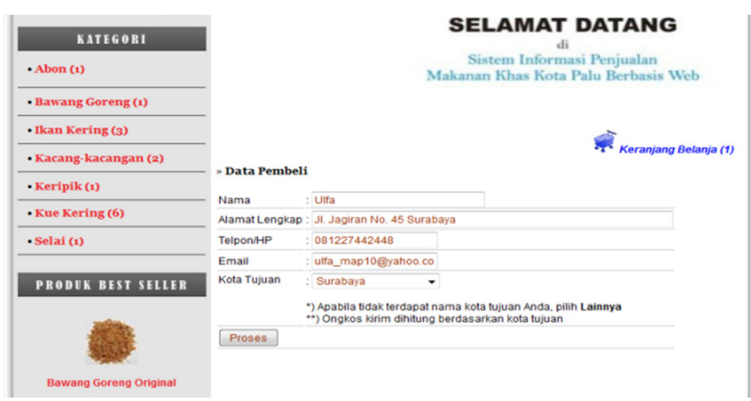

Gambar 11. Tampilan menu data pembeli

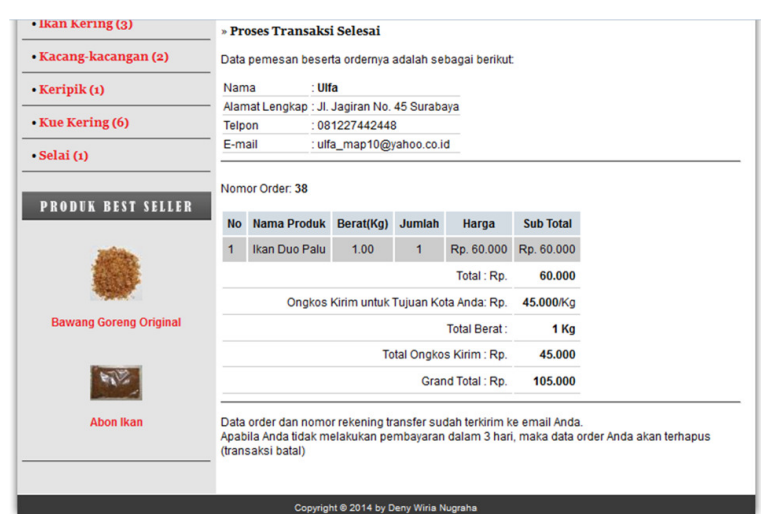

Gambar 12. Tampilan menu proses transaksi

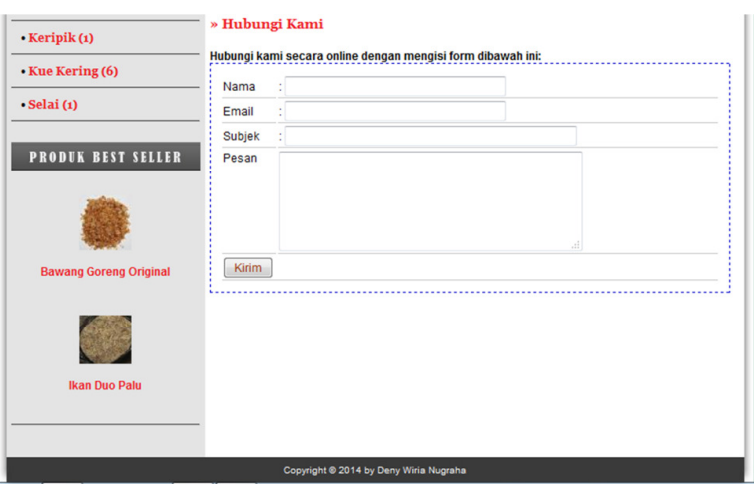

Gambar 13. Tampilan menu hubungi kami

\section{Hasil Pengujian Kemampuan Sistem}

Setelah melakukan serangkaian pengujian terhadap sistem informasi penjualan makanan khas Kota Palu berbasis web yang telah dirancang dan dibangun dalam penelitian ini, maka dapat dijelaskan kemampuan yang dimiliki oleh sistem informasi ini, yaitu:

1. Sistem informasi ini telah mampu melakukan proses pengolahan data (simpan, ubah, hapus, hitung data, dan tampil data) secara tepat dan akurat.

2. Seluruh menu atau halaman web yang terdiri dari menu utama/beranda, menu profil, menu cara pembelian, menu produk, menu keranjang belanja, menu data pembeli, menu proses transaksi, menu hubungi kami, dan halaman administrator, terbukti dapat berjalan dengan baik dan dapat menampilkan informasi secara jelas dan akurat.

3. Informasi, menu-menu, dan tombol yang ada pada sistem informasi ini bisa dipahami tanpa adanya kesulitan.

4. Sistem informasi ini dapat mengontrol akses pengguna (admin) dengan membatasi hak akses. 
5. Sistem informasi ini memiliki desain tampilan yang konsisten pada setiap halamannya.

6. Sistem informasi ini dapat dioperasikan dengan mudah oleh pengguna.

7. Sistem informasi ini dapat memberikan pesan yang jelas saat terjadi kesalahan pengisian.

8. Sistem informasi ini memiliki fasilitas pencarian data produk secara cepat, tepat, dan akurat.

9. Sistem informasi ini mampu mengelola data penjualan, yaitu memberikan informasi produk dan mempermudah transaksi online secara akurat, tepat waktu dan relevan.

10. Sistem informasi ini mampu meningkatkan keunggulan kompetitif antara lain memenuhi kebutuhan konsumen dengan cepat karena hubungan pembeli langsung dengan penjual tanpa perantara, ketersediaan informasi produk secara akurat, memperluas jangkauan geografis, meningkatkan penjualan barang/produk, dan kemudahan dalam bertransaksi tanpa perlu datang ke tempat penjualan karena cukup melihat informasi di website dan mengklik barang/produk yang diinginkan.

11. Sistem informasi ini memiliki konsep electronic commerce (e-commerce) yaitu mampu melakukan perdagangan elektronik berupa penyebaran, penjualan, pembelian, pemasaran barang/produk, dan pemrosesan transaksi online.

\section{V. KESIMPULAN}

Berdasarkan hasil penelitian yang telah dilakukan, maka dapat diambil kesimpulan sebagai berikut:

1. Sistem informasi penjualan makanan khas Kota Palu yang dirancang dan dibangun dalam penelitian ini memiliki konsep electronic commerce (e-commerce) yaitu mampu melakukan perdagangan elektronik berupa penyebaran, penjualan, pembelian, pemasaran barang/produk, dan pemrosesan transaksi online.

2. Sistem informasi ini mampu meningkatkan keunggulan kompetitif antara lain memenuhi kebutuhan konsumen dengan cepat karena hubungan pembeli langsung dengan penjual tanpa perantara, ketersediaan informasi produk secara akurat, memperluas jangkauan geografis, meningkatkan penjualan barang/produk, dan kemudahan dalam bertransaksi tanpa perlu datang ke tempat penjualan karena cukup melihat informasi di website dan mengklik barang/produk yang diinginkan.
3. Kemampuan lainnya yang dimiliki oleh sistem informasi ini adalah mampu melakukan proses pengolahan data (simpan, ubah, hapus, hitung data, dan tampil data) secara tepat dan akurat; seluruh menu atau halaman web yang terdiri dari menu utama/beranda, menu profil, menu cara pembelian, menu produk, menu keranjang belanja, menu data pembeli, menu proses transaksi, menu hubungi kami, dan halaman administrator terbukti dapat berjalan dengan baik dan dapat menampilkan informasi secara jelas dan akurat; informasi, menu-menu, dan tombol yang ada bisa dipahami tanpa adanya kesulitan; dapat mengontrol akses pengguna (admin) dengan membatasi hak akses; memiliki desain tampilan yang konsisten pada setiap halamannya; dapat dioperasikan dengan mudah oleh pengguna; dapat memberikan pesan yang jelas saat terjadi kesalahan pengisian; memiliki fasilitas pencarian data produk secara cepat, tepat, dan akurat; dan mampu mengelola data penjualan, yaitu memberikan informasi produk dan mempermudah transaksi online secara akurat, tepat waktu dan relevan.

Adapun saran dari peneliti adalah sistem informasi ini masih perlu dikembangkan lagi, terutama dalam pengelolaan administrasi keuangan dan pelaporan rekapitulasi penghasilan.

\section{DAFTAR PUSTAKA}

[1] Tohari, H. 2014. Astah - Analisis Serta Perancangan Sistem Informasi Melalui Pendekatan UML, Halaman 7, Penerbit CV. Andi Offset, Yogyakarta.

[2] Pratama, I. P. A. E. 2014. Sistem Informasi dan Implementasinya: Teori \& Konsep Sistem Informasi Disertai Berbagai Contoh Praktiknya Menggunakan Perangkat Lunak Open Source, Halaman 10-14, Penerbit Informatika, Bandung.

[3] Kadir, A. 2014. Pengenalan Sistem Informasi Edisi Revisi, Halaman 22-23, Penerbit CV. Andi Offset, Yogyakarta.

[4] Laudon, K. C., Laudon, J. P. 2005. Sistem Informasi Manajemen, Mengelola Perusahaan Digital, Edisi 8, Halaman 159, Penerbit Andi, Yogyakarta.

[5] Sutabri, T. 2012. Konsep Sistem Informasi, Halaman 108, Penerbit CV. Andi Offset, Yogyakarta. 